\title{
Aplikasi mHealth "SIGA" \\ Untuk Pelayanan Kesehatan Masyarakat Umum Berbasis Android
}

\author{
Akmal Eddy Madda ${ }^{1}$, Moh. Ramli ${ }^{2}$, Ahmad Yani ${ }^{3}$ \\ ${ }^{I}$ Dokter Gigi, Puskesmas Sangurara, Dinas Kesehatan Kota Palu, Indonesia \\ ${ }^{2}$ Puskesmas Sangurara, Dinas Kesehatan Kota Palu, Indonesia \\ ${ }^{3}$ Departemen Promosi Kesehatan, Fakultas Kesehatan Masyarakat, Universitas Muhammadiyah Palu
}

\begin{abstract}
ABSTRAK
Perkembangan aplikasi Android saat ini telah membawa perubahan besar dalam berbagai bidang salah satunya adalah bidang Kesehatan. Memanfaatkan kemajuan teknologi informasi dalam bidang mobile adalah solusinya. Aplikasi mobile berbasis Android untuk memanggil ambulans masyarakat diharap dapat merasa lebih tenang dalam situasi panik. Location-based service digunakan untuk melengkapi fitur aplikasi dibuat. Makalah bertujuan untuk terciptanya sebuah aplikasi pemanggilan ambulans untuk masyarakat umum berbasis Android. Inovasi ini muncul untuk menjawab masalah dimayarakat terkait dengan ketepatan dan kepastian ambulans yang di pesan oleh masyarakat untuk kasus-kasus gawat atau mendesak. Aplikasi SIGA adalah aplikasi yang diciptakan untuk memudahkan masyarakat untuk mengakses layanan ambulans yang tepat dan pasti. Aplikasi SIGA ini merupakan aplikasi yang kemungkinan masih baru khususnya di wilayah sulawesi tengah dimana sebuah puskemas bisa dan mampu untuk membuat sebuah aplikasi yang rancang bangun dan desainnya dirancang langusng oleh kepala puskesmasnya, karenanya tidak dapat melakukan studi banding diwilayah sulawesi tangah , sehingga banyak dilakukan inovasi dan improvisasi sendiri dalam pengembangan nya kedepan
\end{abstract}

Key Words: MHealth, Pelayanan Kesehatan

Correspondence Author:

Akmal Eddy Madda

E-mail: akmal.em@gmail.com

Hp: 081377715684 


\section{PENDAHULUAN}

Sektor telekomunikasi saat ini berkembang pesat karena adanya kemajuan teknologi global khususnya di bidang handphone dan internet [1]. Salah satunya adalah kemajuan pada aplikasi mobile berbasis Android. Perkembangan aplikasi Android saat ini telah membawa perubahan besar dalam berbagai bidang salah satunya adalah bidang Kesehatan [2]. Terdapat beberapa aplikasi yang menyediakan informasi kepada pengguna bagaimana cara hidup yang sehat. Saat ini kebanyakan masyarakat sudah mempunyai smartphone masing-masing, dengan semakin berkembangannya teknologi bukan tidak mungkin untuk bisa mengetahui lokasi sebuah tempat melaui smartphone [3].

Teknologi yang tepat untuk digunakan sebagai media pencarian lokasi pada smartphone adalah Global Positioning System (GPS) yang sudah bisa di jalankan di smartphone dan salah satunya menggunakan platform android. Teknologi Location Based Serviced (LBS) sudah banyak digunakan, namun di butuhkan media informasi yang lebih dari sekedar hanya untuk melihat lokasi, dibutuhkan media informasi yang bisa memberikan jalur dua arah yaitu antara pelanggan dan penyedia jasa. Aplikasi yang menyediakan tombol darurat yang berfungsi menampilkan lokasi mobil ambulan terdekat dan mengirim pemberitahuan ke mobil ambulan terdekat jika terjadi kecelakaan atau penyakit medis yang mengancam jiwa [4], [5].

Pelayanan ambulans merupakan pelayanan transportasi pasien rujukan dengan kondisi tertentu antar fasilitas kesehatan yang disertai dengan upaya atau kegiatan untuk menjaga kestabilan kondisi pasien untuk kepentingan keselamatan pasien [6].

Permasalahan utamanya adalah apakah ada aplikasi yang membantu seseorang untuk mendapatkan penanganan darurat sewaktu-waktu. Kasus kecelakaan saat ini makin sering terjadi dan masyarakat yang ingin menanggulangi kejadian tersebut merasa kesulitan [7]

Masyarakat yang telah melakukan pemanggilan ambulans dengan cara menelepon pihak rumah sakit masih merasa khawatir akan kepastian datangnya ambulans . Beberapa kasus kecelakaan dimana korban tetap tidak dapat diselamatkan karena tidak siapnya penanganan gawat darurat di ambulans ataupun rumah sakit [8]. Masyarakat masih merasa tidak percaya akan ketepatan dan kepastian datangnya ambulans.

Memanfaatkan kemajuan teknologi informasi dalam bidang mobile adalah solusinya. Aplikasi mobile berbasis Android untuk memanggil ambulans masyarakat diharap dapat merasa lebih tenang dalam situasi panik. Location-based service digunakan untuk melengkapi fitur aplikasi dibuat [9].

Aplikasi Panggil Ambulance ini dibangun untuk menyelesaikan masalah kekhawatiran masyarakat akan ketepatan dan kepastian datangnya ambulans.

Makalah ini bertujuan untuk memudahkan masyarakat untuk mendapatkan pelayanan kesehatan secara mandiri melalui aplikasi andorid yang dapat dilakukan di smartphone. 


\section{METODE}

Makalah ini dibuat berdasakan hasil literature review dari berbagai hasil penelitian relevan. Aplikasi tersebut dibuat menggunakan software Juggle Jack, software tersebut merupakan platform penyedia jasa pembuatan aplikasi Android dan di didesain oleh penulis "Akmal Eddy Madda". Aplikasi ini digunakan khususnya pada kondisi darurat. Aplikasi ini dapat digunakan dimana saja dan untuk siapa saja selama terkoneksi dengan jaringan internet. Pengguna dapat memanggil ambulans melalui. Aplikasi ini akan memberikan pelayanan kirim ambulans kepada masyarakat. Pihak yang terkait oleh Puskesmas dalam proses kirim ambulans adalah supir ambulans .Pihak yang berkaitan selain pihak puskesmas dan masyarakat aplikasi ini digunakkan oleh dokter paramedis dan rumah sakit. Pihak puskesmas dan dokter paramedis dapat meminta ambulans untuk pasien dan atau merujuk pasien ke rumah sakit sesuai kondisi yang sedang terjadi. Masyarakat juga dapat mengetahui lokasi dari dokter paramedis dan lokasi puskesmas yang juga menggunakan aplikasi Panggil Ambulance.

Berikut Gambar Aplikasi Berbasis Android yang dinamakan "SIGA"
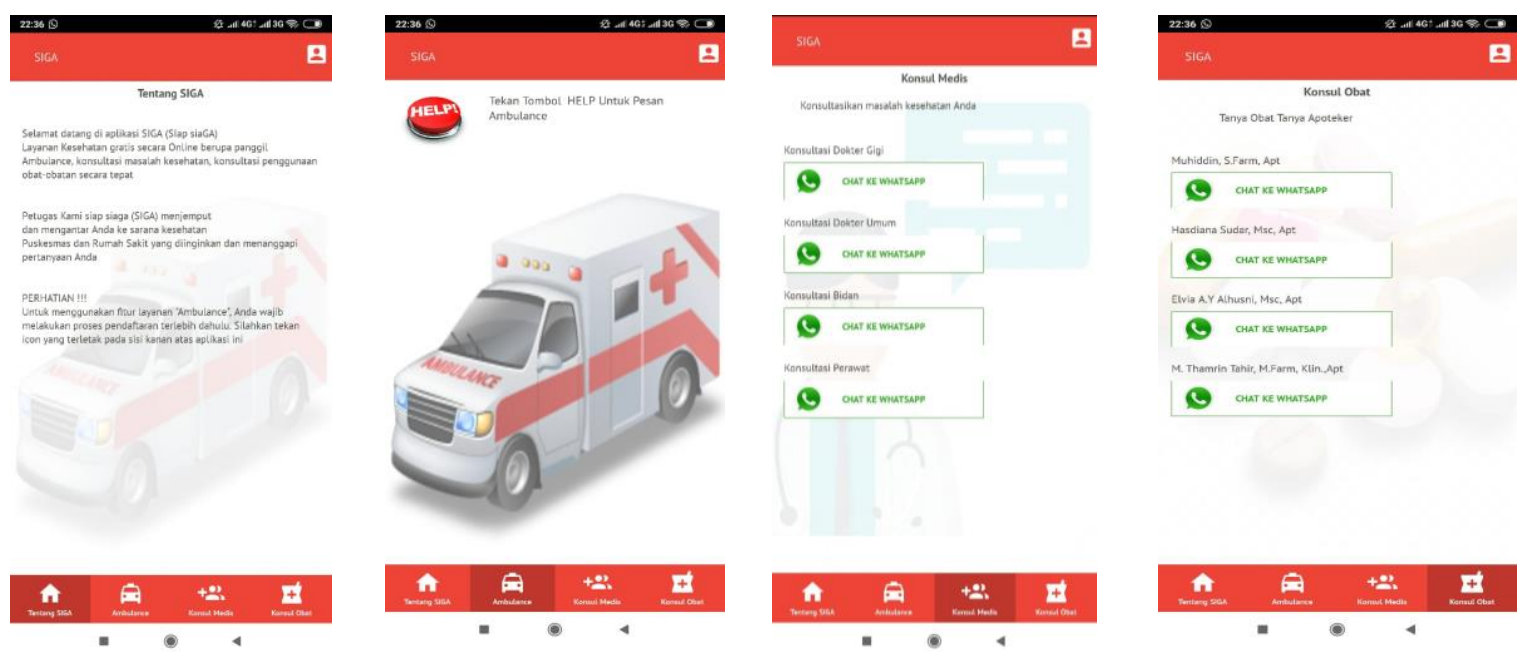

\section{HASIL DAN PEMBAHASAN}

\section{Pendekatan Strategis}

Siapa saja yang telah mengusulkan pemecahannya dan bagaimana inisiatif ini telah memecahkan masalah tersebut?

Berdasarkan pemikiran diatas maka dan melihat fenomena dilapangan dimana masyarakat masih ragu untuk menggunakan atau memanggil ambulans untuk kasus-kasus darurat, maka kami mencoba menjawab masalah tersebut dengan merancang sebuah aplikasi memanggil ambulans dengan berbasis android yang cocok dan mudah diakses, murah, tidak terbatas oleh waktu, jarak, dan tempat, ambulans dapat terpantau oleh pemanggil ambulans sehingga bisa mengetahui posisi dan perkiraan waktu ambulans sampai di tempat [10]. Setelah melakukan pertemuan dengan beberapa pihak khususnya staf Puskesmas Sangurara didapatkan 
sebuah inisiatif yang bisa memfasilitasi hal tersebut yaitu dengan memanfaatkan Aplikasi praktis yang di akses secara online hal ini didasarkan pada pertimbangan bahwa :

1. Smartphone/Android saat ini bukan lagi barang mewah yang hampir semua orang pasti memilikinya

2. Aplikasi bisa di unduh secara gratis

3. Permasalahan utama masayarakat dalam menggunakan atau memanggil ambulans yaitu merasa tidak percaya akan ketepatan dan kepastian datangnya ambulans diharapkan bisa terpacahkan.

\section{Dalam hal apa inisiatif ini kreatif dan inovatif ?}

Aplikasi SIGA memiliki kelebihan antara lain :

1. Aplikasi ini adalah bisa diunduh secara gratis di play store.

2. Layanan ini efesien dan unlimited artinya tidak terbatas pada waktu, tempat dan jarak.

3. Aplikasi Panggil Ambulance ini dibangun untuk menyelesaikan masalah kekhawatiran masyarakat akan ketepatan dan kepastian datangnya ambulans.

4. Masyarakat dapat mengetahui lokasi dari ambulans yang dipanggil.

\section{Pelaksanaan dan Penerapan}

\section{Bagaimana strategi ini dilaksanakan?}

a) Strategi pelaksnaan Aplikasi SIGA secara bertahap dalam hal ada empat tahapan yaitu :

1. Observasi

Dalam tahap ini dilakukan observasi bagaimana keakuratan lokasi pada smartphone Android

2. Analisis

Dalam tahap ini dilakukan analisis terhadap kebutuhan sistem dengan menyusun arsitektur informasi yang tepat untuk menyimpan dan menyajikan informasi data supir ambulans , puskesmas, dokter paramedis, dan masyarakat umum.

3. Perancangan

Dalam tahap ini dilakukan perancangan prototype aplikasi mobile untuk mengirimkan data permintaan ambulans dan aplikasi web yang dapat mengelola informasi pengguna berdasarkan arsitektur informasi yang telah ditetapkan.

4. Implementasi Perangkat Lunak

Dalam tahap ini dilakukan pembangunan aplikasi mobile perancangan prototype aplikasi mobile untuk mengirimkan data permintaan ambulans dan aplikasi web yang dapat mengelola informasi pengguna berdasarkan hasil rancangan yang telah divalidasi sebelumnya

b) Mewujudkan Purwarupa Aplikasi SIGA dalam waktu 2 bulan

c) Melakukan uji coba Aplikasi SIGA, pada tahap pengujian dilakukan terhadap fungsionalitas aplikasi dan terhadap pengguna, serta bagaimana keakuratan lokasi pada smartphone Android 


\section{Siapa saja yang terlibat dalam pelaksanaannya?}

Yang terlibat dalam desain Aplikasi SIGA

Dalam perancangan aplikasi dikerjakan secara mandiri oleh kami, dan dalam proses uji coba aplikasi, melibatkan sopir atau driver ambulans puskesmas sangurara sebagai pihak yang akan menjawab setiap panggilan permintaan ambulans yang masuk di aplikasi SIGA, juga beberapa staf yang berperan sebagai pengguna atau pemanggil ambulans.

\section{Sumber daya apa saja yang digunakan untunk inovasi ini dan bagaimana sumber daya itu dimobilisasi? \\ Dikarenakan rancang bangun dan desain inovasi Aplikasi SIGA dirancang langsung secara mandiri oleh kami maka secara finansial belum membutuhkan dana yang besar dalam hal pembuatannya.}

\section{Apa saja keluaran (output) yang paling ingin dicapai ?}

Hasil yang dicapai oleh inovasi ini adalah

1. Sopir/driver secara cepat dapat menerima panggilan secara detail mulai dari siapa yang memanggil, lokasi rumah, waktu dan jarak ambulans bisa terpantau baik oleh driver ambulans juga oleh pihak yang memesan ambulans.

2. Aplikasi Panggil Ambulance ini diharapkan dapat menyelesaikan masalah kekhawatiran masyarakat akan ketepatan dan kepastian datangnya ambulans.

3. Masyarakat dapat mengakses secara mudah pelayanan ambulans tanpa harus ragu dan khawatir

\section{Sistem apa yang diterapkan untuk memantau kemajuan dan mengevaluasi kegiatan?}

Untuk memantau dan mengevaluasi penerapan Aplikasi SIGA dilaksanakan hal-hal sebagai berikut :

a) Pemantauan aplikasi SIGA terpantau oleh kami sebagai admin aplikasi.

b) Dikerenakan aplikasi ini memanfaatkan GPS maka posisi driver dan pemesan dapat terpantau jelas.

\section{Apa saja kendala utama yang dihadapi dan bagaimana kendala tersebut dapat diatasi?}

Secara umum tidak ada kendala yang berat hanya saja Aplikasi ini merupakan aplikasi yang kemungkinan masih baru khususnya di wilayah sulawesi tengah dimana sebuah puskemas bisa dan mampu untuk membuat sebuah aplikasi yang rancang bangun dan desainnya dirancang langusng oleh kepala puskesmasnya, karenanya tidak dapat melakukan studi banding diwilayah sulawesi tangah, sehingga banyak dilakukan inovasi dan improvisasi sendiri dalam pengembangan nya kedepan, dan keterbatasan aplikasi ini adalah bahwa aplikasi ini masih diperuntukan untuk masyarakat diwilayah kerja UPTD Puskesmas Sangurara, dan kedepannya diharapkan bisa dipakai secara keseluruhan oleh masyarakat Kota Palu dan sekitarnya. 


\section{Dampak Sebelum dan Sesudah}

\section{Apa saja manfaat utama yang dihasilkan inovasi ini ?}

Manfaat untuk Puskesmas :

a) Sebagai sarana evaluasi kinerja driver ambulans dalam melakukan pelyanan transportasi baik itu menjemput pasien maupun merujuk pasien dari Puskesmas/ rumah ke Puskesmas ke Rumah Sakit

b) Sebagai bahan penilaian khusus untuk kepala puskemas dalam hal berinovasi dan mengembangkan kemampuan meciptakan sebuah aplikasi yang bisa diterapkan dan digunakan di Puskesmas Sangurara.

c) Manfaat dari aplikasi ini tidak hanya dirasakan oleh pihak yang membangun aplikasi tersebut tetapi juga dirasakan oleh pihak rumah sakit, supir ambulans, puskesmas, dokter paramedis, serta masyarakat umum.

d) Manfaat bagi pihak Puskesmas adalah dapat mengecek keaslian pemanggilan ambulans yang dilakukan oleh masyarakat.

Sedangkan untuk masyarakat pengguna Aplikasi yang terutama adalah :

a) Aplikasi SIGA bisa menjawab kekhawatiran mereka terhadap ketepatan dan kepastian datangnya ambulans.

b) Posisi, jarak dan waktu keberangkatan dan kedatangan ambulans dapat diketahui secara jelas.

\section{Keberlanjutan}

\section{Apa saja pembelajaran yang dapat dipetik?}

Inovasi ini muncul untuk menjawab masalah dimayarakat terkait dengan ketepatan dan kepastian ambulans yang di pesan oleh masyarakat untuk kasus-kasus gawat atau mendesak.

Bahwa untuk menciptakan sebuah inovasi perlunya setiap petugas kesehatan harus bisa kreatif dan tidak berhenti belajar, aplikasi ini hanya sedikit dari ide yang muncul kepermukaan yang kemudian di di desain dan dibuat serta diterapkan dalam menunjang peningkatan mutu layanan di puskesmas.

\section{KESIMPULAN}

Makalah ini menyimpulkan bahwa Aplikasi SIGA adalah aplikasi yang diciptakan untuk memudahkan masyarakat untuk mengakses layanan ambulans yang tepat dan pasti. Aplikasi SIGA ini merupakan aplikasi yang kemungkinan masih baru khususnya di wilayah sulawesi tengah dimana sebuah puskemas bisa dan mampu untuk membuat sebuah aplikasi yang rancang bangun dan desainnya dirancang langusng oleh kepala puskesmasnya, karenanya tidak dapat melakukan studi banding diwilayah sulawesi tangah, sehingga banyak dilakukan inovasi dan improvisasi sendiri dalam pengembangan nya kedepan. Aplikasi SIGA bentuk inovatif yang mencoba menjawab permasalahan dimasyarakat terkait ketepatan dan kepastian dalam memanggil ambulans. 


\section{REFERENSI}

[1] M. Kay, J. Santos, and M. Takane, "mHealth: New Horizons for Health through Mobile Technologies," World Heal. Organ., 2011.

[2] C. B. Aranda-Jan, N. Mohutsiwa-Dibe, and S. Loukanova, "Systematic review on what works, what does not work and why of implementation of mobile health (mHealth) projects in Africa," BMC Public Health, 2014.

[3] D. Ben-Zeev, S. M. Schueller, M. Begale, J. Duffecy, J. M. Kane, and D. C. Mohr, "Strategies for mHealth Research: Lessons from 3 Mobile Intervention Studies," Adm. Policy Ment. Heal. Ment. Heal. Serv. Res., 2015.

[4] S. M. Tomkiewicz, M. R. Fuller, J. G. Kie, and K. K. Bates, "Global positioning system and associated technologies in animal behaviour and ecological research," Philosophical Transactions of the Royal Society B: Biological Sciences. 2010.

[5] M. S. Grewal, "Global navigation satellite systems," Wiley Interdiscip. Rev. Comput. Stat., 2011.

[6] E. Oncu, S. Koksoy, and M. A. Sungur, "Referral to the hospital and emergency ambulance service uses patterns of the inmates and convicts. [Turkish] $\backslash$ TTutuklu ve hukumlulerin hastaneye sevk nedenleri ve acil ambulans kullanimi ozellikleri," J. Clin. Anal. Med., 2015.

[7] C. L. Barton, "Mobile Health (mHealth) Technologies and Global Markets," 2017.

[8] R. N. Madeira, C. M. Pereira, S. Clipei, and P. Macedo, "ONParkinson - Innovative mhealth to support the triad: patient, carer and health professional," in Lecture Notes of the Institute for Computer Sciences, Social-Informatics and Telecommunications Engineering, LNICST, 2018.

[9] M. N. K. Boulos, S. Wheeler, C. Tavares, and R. Jones, "How smartphones are changing the face of mobile and participatory healthcare: An overview, with example from eCAALYX," BioMedical Engineering Online. 2011.

[10] T. Dehling, F. Gao, S. Schneider, and A. Sunyaev, "Exploring the Far Side of Mobile Health: Information Security and Privacy of Mobile Health Apps on iOS and Android," JMIR mHealth uHealth, 2015. 